\title{
Vulnerability and Poverty Dynamics in Rural Areas of Eastern Cape Province, South Africa
}

\author{
L. J. S. Baiyegunhi \\ University of KwaZulu-Natal, \\ Pietermaritzburg, South Africa. \\ Email:Baiyegunhil@ukzn.ac.za \\ and \\ G. C. G. Fraser \\ Department of Economics and Economic History, \\ Rhodes University, \\ Grahamstown, South Africa. \\ Email:g.fraser@ru.ac.za \\ DOI: http://dx.doi.org/10.4314/gjds.v8i2.6
}

\begin{abstract}
If the aim of studying poverty is not only improving the well-being of households who are currently poor, but also preventing people from becoming poor in the future, a new forward looking perspective must be adopted. This study analyses determinants of household poverty dynamics in rural areas of the Eastern Cape Province, South Africa using a panel dataset on a representative sample of 300 rural households in the Amathole District Municipality. The result of the study shows a significant flow in and out of poverty, which is a sign of vulnerability. While 63\% of the sampled households are poor (ex post), while $48 \%$ are vulnerable to becoming poor (ex ante) in future. The result of the probit model indicates that age, level of education and household heads' occupation, dependency ratio, remittance/diversified income base, exposure to idiosyncratic risks and access to credit are statistically significant in explaining households' vulnerability to poverty. Implications for policy are discussed.
\end{abstract}

Keywords: Vulnerability, Poverty dynamics, Rural, Household, Expenditure. 


\section{Introduction}

Despite South Africa's upper-middle-income country status (GDP per capita is approximately $\$ 10,700$ ) (CIA, 2008), South Africa fares extremely poorly on international comparisons of poverty and other social indicators. For example, its income and wealth distribution is the most unequal in the world with a Gini-coefficient of 0.72 in 2005 (World Bank, 2007), with many South African households living in outright poverty or at the very least are vulnerable to becoming poor (World Bank 2001; Klasen 2000). The poverty rates of households and individuals in the rural areas, according to the Income and Expenditure Survey (2005/06), were 54.2\% and $67.7 \%$ respectively. This is more than double the corresponding rates for urban areas (21.9\% and $32.7 \%$ ). Therefore, $57.1 \%$ of all poor households and 59.3\% of poor individuals were rural dwellers (Armstrong, Lekezwa and Siebrits, 2008).

Rural households in South Africa as in many developing countries are frequently confronted by severe idiosyncratic risks (i.e. household-level shocks, such as human illness, death, injury, unemployment, job loss, asset loss, crop pest and diseases) and covariate risks (i.e. community shocks such as natural disaster or epidemics), resulting in high income volatility, the high incidence of HIV/AIDs, which has caused considerable losses of human lives and disruption of livelihoods. These events have shaped the fortunes of households and affected their mobility across the survival threshold. Therefore, reducing poverty and inequality are an obvious concern for policy-makers since the advent of democratic governance in South Africa.

There have been policies aimed at reducing poverty and vulnerability and those aimed at increasing upward mobility of previously disadvantaged South Africans. These include the affirmative action legislation, racial equalization, expansion of educational spending, the expansion of a social safety net, greater labour market protection for low-skilled workers, expansion of water and electricity supply and other infrastructure to previously underserved communities, a land reform program and a macroeconomic reform that has aimed to deliver faster growth with distribution. Others have been aimed at reducing dependency of the poor on the vagaries of the labour market as well as demographic and other shocks, including old age (social grant), pensions, public works programmes, disaster relief, child grants and disability grants (May, 1998).

With these policies in place for the rural poor in South Africa, there is no gainsaying that the democratic government is aiming in the process to increase the income mobility of previously disadvantaged South Africans. Therefore, there is need to look into intertemporal mobility i.e. who is getting ahead, who is falling behind, who is standing still and why? This is important from an instrumental perspective, because of the many risks households face; they often experience shocks leading to wide variability in their endowment and income (Christiansen and Subbarao, 2005). Also, the role of demographic and economic events needs to be clearly examined. It is expected that changes in 
demographic and employment would play a significant role in explaining mobility in South Africa (Case and Deaton, 1998; Klasen and Woolard, 2001).

There are relatively few studies on poverty dynamics in South Africa. This is partly due to the absence of reliable panel data sets. However, Carter and May (2001) used, exclusively, expenditure data and transition matrices with exogenously fixed boundaries to study the movement in and out of poverty in relation to the asset base of the poor, asset and entitlement shocks. They also attempted to distinguish between what they term structural and stochastic causes for this mobility. The result of the study indicates a considerable mobility between 1993 and 1998.

In another study, Fields, Chicello, Freije, Menendez and Newhouse (2002) analysed household income dynamics in four countries including South Africa using the KwaZuluNatal Income Dynamics Survey (KIDS) data. They used household per capital income to determine whether there was convergence of household incomes between the two periods considered. Fields and associates (2003) further studied the determinants of household income change and considered initial demographic and labour market conditions as well as their changes. They found that changes in employment status of household head as well as initial income had the largest impact on income changes.

Woolard and Klasen (2005) studied the determinants of income mobility and household poverty dynamics among Africans in KwaZulu-Natal Province of South Africa. They used data from the 1993 Project for Statistics on Living Standards and Development (PSLSD) and 1998 KIDS survey. The result of the study shows that demographic changes and employment changes account for most of the mobility observed which is related to rapidly shifting household boundaries and a very volatile labour market in an environment of high unemployment.

This current study differs from the above studies in that it seeks to understand short-term poverty dynamics by focusing on rural households and using panel data, which rely upon a time unit that is less, or equal to a year. Generally, the movements in and out of poverty are assessed on a yearly basis (e.g. Baulch and Hoddinott, 2000; Jalan and Ravallion, 1999 and 2000). Secondly, this study does so by attempting to identify vulnerable households which have been explicitly defined as a combination of those always poor and becoming poor in the two survey rounds.

\section{Study Data and Analytical Technique}

\section{Study area and data}

This study was conducted in the Amathole District Municipality of the Eastern Cape Province. The Eastern Cape is home to about 7 million individuals and about 204000 are working in the agricultural sector (Statistics South Africa, 2007a). Therefore $2.9 \%$ of the Eastern Cape population is working in the agricultural sector, but agriculture contributed 
only $1.7 \%$ to the regional economy in 2006 (Statistics South Africa, 2007b). In per capita income terms, the province is one of the poorest, with the Limpopo Province being worst off. The province in particular includes a wealthy metropolitan area (East London) with poor shantytowns surrounding it, a poor and largely rural former homelands Transkei and Ciskei, with a high poverty and unemployment rate, which is often linked directly to the historical economic neglect of these areas.

Structured questionnaires were used to collect data from household heads on their demographic, socio-economic characteristics, income and expenditure from a tworound panel survey at one year interval. To allow for inclusion of time-variant household effects and dynamic effects and in some cases to get a sense of the magnitude of biases in estimates of vulnerability generated from cross-sectional data, this study used a panel data (see Ellis, 2000; Sen, 2003). The first round survey was carried out in 2007 , with a resurvey of the same households in 2008. This was to reduce sample attrition between the two periods.

A multistage stratified random sampling technique (Barnett, 1991) was used to select representative households for the study. The first stage involved the selection of three local municipalities, viz. Ngqushwa, Amahlathi and Nkonkobe. The second stage involved random sampling of six villages within these local municipalities from which 50 respondents each were randomly selected. These villages were Peddie and Hamburg for Ngqushwa, Stutterheim and Keiskammahoek for Amahlathi, and Alice and Seymour for Nkonkobe. In the second survey round in 2008, purposive sampling was used in order to track the characteristics of the households at the two different periods.

\section{Analytical technique}

\section{Determination of poverty lines}

The poverty line is the level of welfare that distinguishes poor households from non-poor households. This is a pre-determined and well defined standard of income or value of consumption (expenditure). Poverty lines are often drawn either in relative or absolute terms. The absolute poverty line is a predetermined one based on some minimum food and non-food expenditure below which a household is defined as poor if its consumption level is below this minimum (Ravallion, 1992; Deaton, 1997). In other words, the poverty line is fixed in terms of the standard of living it commands over the domain of poverty measurement.

To get a consistent picture of household welfare during the two rounds of the survey, it was necessary to use poverty lines, which could be comparable across the country and through time. Therefore, the "lower bound" of the absolute poverty line proposed by Statistics South Africa, which provides for essential food and non-food consumption amount to R322 per capital per month in 2000 prices, was used for this study. 
The choice of a consumption-based rather than an income-based measure of household welfare is motivated by the fact that, income can be viewed as a measure of welfare opportunity or a measure of potential welfare whereas consumption on the other hand can be interpreted as a realized welfare or a measure of welfare achievement (Hentschel and Lanjouw, 1996; Atkinson, 1989). Since realised rather than potential welfare is the concept of interest, consumption is arguably a more appropriate indicator. Moreover, expenditure might, in most cases, be more accurately captured particularly among the poor who have relatively constant and well known expenditures on relatively few items while incomes can be erratic and unpredictable (Ravallion, 1992; Deaton, 1997; Klasen, 200o). The household's consumption expenditures were corrected for household size and its demographic characteristics following Deaton and Muellbauer (1980) as follows:

(1) Adult equivalent expenditure $=\frac{H E}{(A+a K) q}$

where, $H E=$ Household expenditure

$A=$ Number of adults

$K=$ Number of children

$\mathrm{a}=$ Fractional representation of children in adult equivalence i.e. child cost ratio

$\mathrm{q}=$ Scale parameter

Most poverty studies in South Africa have adopted the values of $\mathrm{a}=0.5$ and $\mathbf{q}=0.9$ (May et al., 1995). The mean monthly per adult equivalent household expenditure (MPAEHE) of the sampled households was determined by dividing the total per adult equivalent expenditure for all households by the total number of households sampled. Hence, extremely (core) poor, moderately poor and non-poor household were identified.

\section{Measuring poverty dynamics: A transition matrix}

In order to measure mobility, a two-stage index is used. The two-stage index first allocates individuals to income groups (either exogenously fixed income groups or endogenously determines ones like quintiles) and then examines mobility between these groups. When two observations in time are available (in a panel or in a cross-section which contains a quasi-panel component), a transition matrix and indices derived from it can be used to map changes i.e. improvement or decline in household welfare (see Dercon, 2001).

Table1: Transitional matrix box

\begin{tabular}{|l|l|l|l|}
\hline & Poor & Non-poor & Total \\
\hline Poor & $\mathrm{p}_{1}$ & $\mathrm{p}_{2}$ & $\mathrm{p}_{1+} \mathrm{p}_{2}$ \\
\hline Non - poor & $\mathrm{P}_{3}$ & $\mathrm{p}_{4}$ & $\mathrm{p}_{3+} \mathrm{p}_{4}$ \\
\hline
\end{tabular}




\begin{tabular}{|l|l|l|l} 
Total & $\mathrm{p}_{1+} \mathrm{p}_{3}$ & $\mathrm{p}_{2+} \mathrm{p}_{4}$ & $\mathrm{Z}$ \\
\hline
\end{tabular}

Source: Adapted from Adesanoye and Okunmadewa, 2007.

where;

$\mathrm{p}_{1}=$ Numbers of households that were poor in the two survey rounds.

$\mathrm{p}_{2}=$ Numbers of households that were poor in the first round but non - poor in the second survey round.

$\mathrm{p}_{3}=$ Numbers of households that were non - poor in the first round but poor in the second survey.

$\mathrm{p}_{4}=$ Numbers of households that were non - poor in the two survey rounds.

$Z=$ Total numbers of households i.e. $\left(\mathrm{p}_{1+} \mathrm{p}_{2+} \mathrm{p}_{3+} \mathrm{p}_{4}\right)$.

Households were grouped based on the measure of poverty as follows:

- The probability of being always poor defined as being poor in the two survey rounds.

- The probability of becoming poor defined as being non-poor in the first round but poor in the second survey.

Clearly, measuring vulnerability is important because it enables the identification of those who are not poor but may fall into poverty and those who will remain poor. A measure that can be used as proxy for vulnerability is the movements in and out of poverty (entry and exit probability). Although, Zhang and Wan (2006) have demonstrated that most researchers prefer to define vulnerability as the probability of a household or individual falling into poverty in the future. This study have defined vulnerable households as a combination of those always poor and those becoming poor, and vulnerability index as a ratio of the number of vulnerable household in the sub-group to the total number of households in the subgroup (see Adesanoye and Okunmadewa, 2007).

\section{Model specification for determinants of household's poverty dynamics (welfare change)}

The probit model was used to identify the factors which influence the dynamics of household welfare (i.e. households' movements in and out of poverty) between the first and second round survey. The probit model assumes that while we observe the values of o and 1 for the variable $W$, there is a latent unobserved continuous variable ${ }^{W_{i}^{*}}$ that determines the value of ${ }^{W}$; we assume that ${ }^{W_{i}}$ can be specified as follows:

(2) $W_{i}^{*}=\mathrm{b}^{\prime} X_{i}+\mathrm{e}_{i}>0 \mathrm{e}_{i} \sim(0,1)$ 


$$
W=\left\{\begin{array}{l}
1 \\
0
\end{array}\right.
$$

where, $W=1$ if $W_{i}^{*}>0$ and $W=0$ Otherwise

i.e. the dependent variable ${ }^{(W)}$ in the probit model is dichotomous assuming a value of 1 if household is vulnerable, i.e. always poor + becoming poor and o if not vulnerable.

The welfare indicator $W_{i}^{*}$ is given as:

$$
\text { (3) } \quad W_{i}^{*}=\frac{Z-Y_{i}}{Z}
$$

where, $Z$ is the poverty line and ${ }^{Y_{i}}$ is the consumption expenditure per adult equivalent. The vector of independent variables is denoted by $X_{i}$. $b$ is the vector of unknown coefficients and ${ }^{\mathrm{e}_{i}}$ is an independently distributed error term.

(4)

$$
\operatorname{Pr}\left(W_{i}=1\right)=\left(\mathrm{b}_{0}+\mathrm{b}^{\prime} X_{i}+\mathrm{e}_{i}>0\right)
$$

Rearranging the terms

$$
\begin{aligned}
& \operatorname{Pr}\left(W_{i}=1\right)=\operatorname{Pr}\left[\varepsilon_{i}>-\left(\beta_{0}+\beta^{\prime} X_{i}+\mu_{i}\right)\right\rfloor \\
& =1-\operatorname{Pr}\left[\varepsilon_{i}<-\left(\beta^{\prime} X_{i}+\mu_{i}\right)\right\rfloor
\end{aligned}
$$

If we make the usual assumption that the error term is normally distributed, we have;

$$
\text { (5) } \quad \begin{aligned}
\quad & 1-\operatorname{Pr}\left[\varepsilon_{i}<-\left(\beta^{\prime} X_{i}+\mu_{i}\right)\right\rfloor \\
& =1-\Phi\left\lfloor\left(-\beta^{\prime} X_{i}\right)\right\rfloor \\
& =\Phi\left\lfloor\left(\beta^{\prime} X_{i}\right)\right\rfloor
\end{aligned}
$$

where, $\Phi=$ Standard cumulative normal distribution; ${ }^{X_{i}}=$ Vectors of independent variables and $\mathrm{b}=$ Estimates of coefficients which give the impact of the independent variables on the latent variable ${ }^{W_{i}^{*}}$. The model can be stated in general form as:

$$
W=f\left(X_{1}, X_{2}, X_{3}, X_{4}, \ldots \ldots \ldots \ldots X_{n}\right)
$$

The explanatory variables $\left(X_{1}, X_{2}, X_{3}, X_{4}, \ldots \ldots \ldots \ldots X_{n}\right)$ used to explain these movements into and out of poverty are presented in Table 2 . 
Table 2: Explanatory variables used in the probit model

\begin{tabular}{|c|c|c|}
\hline Variables & Measurement and units & $\begin{array}{l}\text { Expected effect on } \\
\text { vulnerability }\end{array}$ \\
\hline Gender & Male $=1 ;$ Female $=0$ & $+/-$ \\
\hline Age & $\begin{array}{l}\text { Age of Household head } \\
\text { (in years) }\end{array}$ & + \\
\hline Education & $\begin{array}{l}\text { Years of school attendance } \\
\text { (in years) }\end{array}$ & - \\
\hline Marital status & $\mathrm{D}=1$ if married; $\mathrm{o}$ if otherwise & - \\
\hline $\begin{array}{l}\text { Occupation of } \\
\text { household head }\end{array}$ & $D=1$ if farming; $o$ if otherwise & $+/-$ \\
\hline Dependency ratio & $\begin{array}{l}\text { The number of dependants (aged o-14 and } \\
\text { over the age of } 65 \text { ) to the total household } \\
\text { size, expressed as a percentage. }\end{array}$ & + \\
\hline $\begin{array}{l}\text { Household head access } \\
\text { to credit }\end{array}$ & $D=1$ if with credit access; 0 if otherwise & - \\
\hline $\begin{array}{l}\text { Remittance/diversified } \\
\text { income }\end{array}$ & $\begin{array}{l}\text { Number of sources of remittances/ } \\
\text { income }\end{array}$ & - \\
\hline Access to land & $\begin{array}{l}\text { Household access to land use } \\
\text { Yes }=1 ; \mathrm{No}=0\end{array}$ & - \\
\hline Social capital & Number of associations belonged to & - \\
\hline $\begin{array}{l}\text { Exposure to covariate } \\
\text { risks of household head }\end{array}$ & $D=1$ if exposed; $o$ if otherwise & + \\
\hline $\begin{array}{l}\text { Exposure to } \\
\text { idiosyncratic shock of } \\
\text { household head }\end{array}$ & $D=1$ if exposed; 0 if otherwise & + \\
\hline
\end{tabular}

Source: Based on a priori expectations

Since the explanatory variables included in the probit model are the outcome of ex-ante expectations, no unambiguous predictions on the signs of these variables effects on vulnerability can be made. The education level and marital status of the household head are all expected to a have negative influence on a household being vulnerable to poverty. Households' head's access to land, credit and a higher degree of social capital could also reduce the probability of a household being vulnerable to poverty. A higher degree of 
exposure to covariate and idiosyncratic risks, old age, and a high dependency ratio are likely to increase a households' vulnerability to poverty. Household heads' gender and occupation are likely to have indeterminate sign ceteris paribus.

\section{Empirical Results}

\section{Movement in and out of poverty in the study area}

The "lower bound" of the absolute poverty line proposed by Statistics South Africa, which provides for essential food and non-food consumption amount to R322 per capital per month in 2000 prices, was used for this study. Therefore, households that had a mean Monthly per Adult Equivalent Household Expenditure (MPAEHE) below or equal to R322 were considered poor in both survey rounds, while a household with MPAEHE above these amounts is considered non-poor during these periods. Table 3 presents a transition matrix depicting the movements in and out of poverty in the study area between 2007 and 2008.

Table 3: Movement in and out of poverty (in percentages) $(n=300)$

\begin{tabular}{|l|l|l|l|}
\hline \multirow{2}{*}{ Poverty status in 2007} & \multicolumn{3}{l|}{ Poverty status in 2008} \\
\cline { 2 - 4 } & Poor & Non-poor & Total \\
\hline Poor & $29 \leftrightarrow$ & $15 \uparrow$ & 44 \\
\hline Non-poor & $33 \downarrow$ & $23 \leftrightarrow$ & 56 \\
\hline Total & 62 & 38 & 100 \\
\hline
\end{tabular}

Source: Calculated from field survey data

The incidence of poverty and vulnerability by socio-economic characteristics of the sampled households between 2007 and 2008 is presented in Table 4. The incidence of poverty was higher both in the second round of the survey than the vulnerability index.

Table 4: Poverty incidence and vulnerability by socio-economic characteristics

\begin{tabular}{|l|l|l|l|l|}
\hline \multirow{2}{*}{ Socio-economic characteristics } & \multirow{2}{*}{$(\mathbf{n})$} & \multicolumn{2}{|l|}{ Poverty incidence } & \multirow{2}{*}{ Vulnerability Index } \\
\cline { 3 - 4 } & & 2007 & 2008 & \\
\hline Gender of household head & 108 & $\begin{array}{l}0.41 \\
0.46\end{array}$ & $\begin{array}{l}0.66 \\
0.50\end{array}$ & $\begin{array}{l}0.38 \\
0.62\end{array}$ \\
\hline Male & 192 & & \\
Female & &
\end{tabular}




\begin{tabular}{|c|c|c|c|c|}
\hline $\begin{array}{l}\text { Single } \\
\text { Married }\end{array}$ & $\begin{array}{l}112 \\
188\end{array}$ & $\begin{array}{l}0.42 \\
0.36\end{array}$ & $\begin{array}{l}0.96 \\
0.36\end{array}$ & $\begin{array}{l}0.96 \\
0.43\end{array}$ \\
\hline \multicolumn{5}{|l|}{ Age } \\
\hline $\begin{array}{l}25-39 \\
40-59 \\
60-69\end{array}$ & $\begin{array}{c}122 \\
150 \\
28\end{array}$ & $\begin{array}{l}0.62 \\
0.24 \\
0.71\end{array}$ & $\begin{array}{l}0.32 \\
0.66 \\
1.00\end{array}$ & $\begin{array}{l}0.32 \\
0.66 \\
1.00\end{array}$ \\
\hline \multicolumn{5}{|l|}{ Education } \\
\hline $\begin{array}{l}\text { Illiterate (o) } \\
\text { Primary (1-5 yrs schooling) } \\
\text { Middle (6-9 yrs schooling) } \\
\text { Matric and above (10+ yrs } \\
\text { schooling) }\end{array}$ & $\begin{array}{c}58 \\
68 \\
114 \\
60\end{array}$ & $\begin{array}{l}1.00 \\
0.73 \\
0.21 \\
0.00\end{array}$ & $\begin{array}{l}1.00 \\
0.79 \\
0.45 \\
0.07\end{array}$ & $\begin{array}{l}1.00 \\
0.70 \\
0.68 \\
0.07\end{array}$ \\
\hline \multicolumn{5}{|l|}{ Occupation } \\
\hline $\begin{array}{l}\text { Farming households } \\
\text { Others }\end{array}$ & $\begin{array}{c}268 \\
32\end{array}$ & $\begin{array}{l}0.48 \\
0.12\end{array}$ & $\begin{array}{l}0.58 \\
0.31\end{array}$ & $\begin{array}{l}0.67 \\
0.25\end{array}$ \\
\hline \multicolumn{5}{|l|}{ Dependency ratio } \\
\hline $\begin{array}{l}\text { 0-100\% } \\
\text { Above 100\% }\end{array}$ & $\begin{array}{l}250 \\
50\end{array}$ & $\begin{array}{l}0.33 \\
1.00\end{array}$ & $\begin{array}{l}0.67 \\
1.00\end{array}$ & $\begin{array}{l}0.67 \\
0.40\end{array}$ \\
\hline \multicolumn{5}{|l|}{ Credit constraint status } \\
\hline $\begin{array}{l}\text { Yes } \\
\text { No }\end{array}$ & $\begin{array}{l}244 \\
56\end{array}$ & $\begin{array}{l}0.54 \\
0.00\end{array}$ & $\begin{array}{l}0.68 \\
0.00\end{array}$ & $\begin{array}{l}0.77 \\
0.00\end{array}$ \\
\hline \multicolumn{5}{|l|}{ Land ownership } \\
\hline $\begin{array}{l}\text { No } \\
\text { Yes }\end{array}$ & $\begin{array}{l}280 \\
20\end{array}$ & $\begin{array}{l}0.60 \\
1.00\end{array}$ & $\begin{array}{l}0.60 \\
0.00\end{array}$ & $\begin{array}{l}0.67 \\
0.00\end{array}$ \\
\hline \multicolumn{5}{|l|}{ Social Capital } \\
\hline $\begin{array}{l}0 \\
1-2 \\
\text { Above } 2\end{array}$ & $\begin{array}{c}54 \\
190 \\
56\end{array}$ & $\begin{array}{l}1.00 \\
0.38 \\
0.11\end{array}$ & $\begin{array}{l}1.00 \\
0.53 \\
0.21\end{array}$ & $\begin{array}{l}1.00 \\
0.60 \\
0.55\end{array}$ \\
\hline
\end{tabular}

Source: Calculated from field survey data.

The headcount index of poverty has increase from 0.44 in 2007 to 0.63 in 2008. Although the headcount index of poverty in 2008 was 0.63 the vulnerability index was 0.48 , implying that 48 per cent of the sampled households are vulnerable to poverty. About 67 per cent of the households that were poor in 2007 remained poor in 2008 (i.e. 88 of 132 households translating to 29 per cent of the sampled households), while 33 per cent 
of those households had emerged out of poverty by 2008 (i.e. 44 of 132 households translating to 15 per cent of the sampled households). In addition, about 60 per cent of the non-poor households in 2007 had fallen in poverty by 2008 (i.e. 100 of 168 households translating to 33 per cent of the sampled households), while about 40 per cent of those households remained non-poor in the two survey rounds (i.e. 68 of 168 households translating to 23 per cent of the sampled households). This result suggests a significant flow in and out of poverty, which is a sign of vulnerability. About 63 per cent of the sampled households are vulnerable to poverty (i.e. always poor + becoming poor).

Female households are poorer compared to male headed households in 2007 while in 2008, the reverse was the case. This implies that both male and female headed households could indeed be poor depending on their exposure to risks. However, the vulnerability index suggests that female headed households are more vulnerable to poverty compared to the male headed households. The incidence of poverty was also highest among single (unmarried) household heads compared to the married household heads in both survey rounds. Vulnerability index however shows that single (unmarried) households are more vulnerable to poverty.

In the first and second survey rounds, higher incidence of poverty was found among household heads aged 60 years and above. In support of this, household becomes more vulnerable to poverty with an increase in the age of the household head. Vulnerability index was highest for household heads aged 60 years and above as compared to those aged between 40-59 years and those aged between 25 - 39 years who are the least vulnerable. All household heads with no formal education remain poor in both survey rounds. The vulnerability index for this group was the highest, while those with more than 10 years of schooling have lower incidence of poverty in both survey rounds and are less vulnerable to becoming poor. However, the incidence of poverty among farming households is on the increase. Farm households are more vulnerable to poverty compared to those in other sectors of the economy.

Expectedly, households with high dependency ratio have the highest incidence of poverty in both survey rounds and are more vulnerable to becoming poor. This may be due to the fact that a household with many dependents tends to exert more pressure on household resources. The incidence of poverty was also high among households that have constrained access to credit in both survey round, and as a result are more vulnerable to becoming poverty. Households that have access to land have low incidence of poverty in both survey rounds compared to those without access to land and are less vulnerable to becoming poor. Also, households that are members of association/clubs or societies have less incidence of poverty and are less vulnerable to becoming poor compared to those who are not members of any association.

\section{Estimate of the determinants of household poverty dynamics}


The probit model was used to estimate the determinants of household vulnerability to poverty. The estimates of the result of the probit analysis are presented in Table 5. The explanatory variables included in the model have been chosen using an iterative procedure. A broad impression of poverty dynamics was first obtained from a theoretical model, which was later fine-tuned as data were accumulated by means of OLS regression analyses of the dependent variable on various combinations of explanatory variables.

Table 5: Estimated coefficients for the probit model of a household vulnerability to poverty

\begin{tabular}{|c|c|c|c|c|}
\hline Variables & $\begin{array}{l}\text { Estimated } \\
\text { Coefficients }\end{array}$ & $\begin{array}{l}\text { Standard } \\
\text { Errors }\end{array}$ & z-statistics & $P[|Z|>z]$ \\
\hline Constant & $-2.7978^{* * *}$ & 0.6475 & $-4 \cdot 3200$ & 0.0000 \\
\hline Gender & 0.2794 & 0.2796 & 1.0000 & 0.3180 \\
\hline Age & $0.0323^{* *}$ & 0.0139 & 2.3237 & 0.0364 \\
\hline Education & $-0.1249^{*}$ & 0.0692 & -1.8049 & 0.0642 \\
\hline Marital status & -0.1313 & 0.1573 & -0.8347 & 0.4040 \\
\hline Access to land & 0.0855 & 0.2878 & 0.2971 & 0.7660 \\
\hline Occupation & $0.2156^{* * *}$ & 0.0710 & 3.0370 & 0.0032 \\
\hline Dependency ratio & $0.1367^{* * *}$ & 0.0384 & 3.6056 & 0.0081 \\
\hline $\begin{array}{l}\text { Remittance/diversified } \\
\text { income }\end{array}$ & $-1.2070^{*}$ & 0.6680 & -1.8072 & 0.0811 \\
\hline Access to credit & $-0.0332^{* * *}$ & 0.0080 & -4.1482 & 0.0072 \\
\hline Social capital & 0.1568 & 0.5040 & 0.3111 & 0.7560 \\
\hline $\begin{array}{l}\text { Exposure to idiosyncratic } \\
\text { risks } 0.0015^{* *}\end{array}$ & $0.0015^{* *}$ & 0.0006 & 2.5000 & 0.0170 \\
\hline $\begin{array}{l}\text { LR Chi2 }(10)=\quad 30.46 \\
P r o b>C h i 2=0.0001 \\
\text { Proportion of correct pr }\end{array}$ & ns $=0.87$ & & \multicolumn{2}{|c|}{$\begin{array}{l}\text { Pseudo } R_{2}=0.2109 \\
\text { Log likelihood }=-56.9743\end{array}$} \\
\hline
\end{tabular}

Source: Probit regression estimation using the software STATA 10.

Note: ${ }^{* *},{ }^{* *}$, and ${ }^{*}$ denote statistical significance at the 1, 5 and $10 \%$ levels, respectively.

The result of the probit analysis above shows that the coefficient of the age of household heads is statistically significant and positively related to household's vulnerability to poverty. This implies that the likelihood of a households' becoming vulnerable to poverty 


\section{J. S. Baiyegunhi \& G. C. G. Fraser}

Vulnerability and Poverty Dynamics in Rural Areas of Eastern Cape Province, South Africa

increases with an increase in the age of the household head. This could be due to the fact many elderly people have to fend for themselves and in most cases do not have others on whom to rely for support. Although many receive old-age grant but as demonstrated by Robert (2001), these grants are in no way sufficient to keep a household out of poverty. Thus, the degree to which a poor elderly person manages to escape poverty, would generally depend on changes in the household circumstances, for instance if a household member secures a good job, there is a decline in dependency ratio accompanied by some relief of financial burdens. Some assets values tend to increase with age.

The coefficient of household education as measured by years of schooling is statistically significant and negatively related to vulnerability to poverty. This implies that households become less vulnerable to poverty with an increasing educational attainment, i.e. the higher the years of schooling the lower the odds that a household head will be vulnerable to poverty. This conforms to other studies concluding that educational attainment decreases poverty (e.g. World Bank, 2002). With an increase in educational attainment, a household head could secure a job and access opportunities which would otherwise not be possible. Higher educational attainment also means better coping with risk and uncertainty and reduced vulnerability to poverty. Education is expected to lead to increased earning potential and improve occupational and geographical mobility of labour. Higher levels of educational attainment will provide higher levels of welfare for the household.

The coefficient of household primary occupation is statistically significant and positively related to household's vulnerability to poverty. This implies that a farming household is more likely to be vulnerable to poverty compared to those in other sectors of the economy. The vast majority of the households are stuck in rural areas and are engaged in farming but do not own land and other resources to progress as farmers. These would lead one to expect that agriculture in these rural areas is unlikely to provide any notable welfare benefits (Aliber, 2003).

The estimated coefficient of households' dependency ratio is statistically significant and positively related to its vulnerability to poverty, implying that the larger the dependency ratio, the more the likelihood of a household becoming vulnerable to poverty. This could be as a result of much pressure exerted on the limited resources at the household level.

The coefficient of household exposure to idiosyncratic risk is statistically significant and positively related to household's vulnerability to poverty. This implies that households exposed to household level shock such as illness, job loss, death, injury/disability, unemployment, crop pest and diseases are vulnerable to becoming poor. This is because these unanticipated events will erode the households' economic base and deplete its resources/assets.

The estimated coefficient of household remittances/diversified income base is statistically significant and negatively related to household's vulnerability to poverty. According to May et al. (1995), diversified income base can help reduce household vulnerability 
to income shock and could be a proxy for household's ability to respond to economic changes. Similarly, the coefficient of credit availability is statistically significant and negatively related to household's vulnerability to poverty. This implies that households with access to credit are less likely to be vulnerable to poverty. When a household takes on a loan to invest, it increases the chance that the household will escape poverty, as increased access to credit market enhances household welfare through the provision of investment credit to boost household income (Adugna and Heidhues, 2000) as well as smooth consumption (Zeller, Von Braun, Johm, and Puetz, 1994). Access to credit could significantly influence a household's income by helping its members to tap economic opportunities, thereby assisting them to get out of poverty (Binswinger and Khandker, 1995; Adugna and Heidhues, 2000).

\section{Conclusion and Policy Implications}

This study aimed to assess, empirically, the dynamics of poverty as well as the determinants of vulnerability to poverty in the study area. The results revealed that while the headcount index of the poor is 0.63 , the vulnerability index is 0.48 . This implies that while $63 \%$ of the sampled households are poor (ex post) in $2008,48 \%$ are vulnerable to becoming poor (ex ante) in future. A large number of households that are now non-poor are certainly vulnerable to descending into poverty in future. This has a policy implication and it is imperative for policy makers to note this when designing social policy. Ex-ante strategies should be developed to prevent households from becoming poor as well as expost strategies to alleviate poverty for those already sunk in poverty.

The result of the probit model shows that the age, level of education and occupation of the household head, dependency ratio, remittances/diversified income base and access to credit are statistically significant in explaining a households' vulnerability to poverty. Education is found to be an important element in reducing vulnerability. Therefore, government may consider investment in human capital as an important elements of their poverty reduction strategy by stimulating access to good quality education along with other means of social protection/promotion (such as old age grants, especially for the elderly who are the most vulnerable) could be instrumental for reducing household vulnerability to poverty. Farming households again are found to be more vulnerable than non-farming households. This underscores the need for more protection for the farming community.

As will be noted, anti-poverty and anti-vulnerability strategies are similar. The only difference is that vulnerability puts ahead the importance of social protection and promotion programmes for ensuring inclusiveness in the development process so that growth becomes more pro-poor. It is also important for policy makers to note the varying nature of poverty and vulnerability in designing policies. For instance, the chronic poor who lack productive and economic assets, priority should be given to reduction of consumption fluctuations and building up of assets through the combination of 
protective and promotional programmes. For example, access to micro-credit might help build up assets as it smoothens income and consumption, enhances the purchases of inputs and productive assets and provides protection against risks. Furthermore, the non-poor but vulnerable household are most likely to benefit from some combination of prevention, protection and promotion which would give them a more secure base to diversify their production activity into higher-return and higher risk activities.

\section{References}

Adesanoye, A.O. and Okunmadewa, F.Y. (2007). Households' vulnerability to poverty in Ibadan Metropolis, Oyo State, Nigeria. Pakistan Journal of Social Sciences, 4(1), pp. $120-128$.

Adugna, T. and Heidhues, F (2000). "Determinants of farm households access to informal credit in Lume District, Central Ethiopia." Savings and Development, 24(4), pp. 27 46.

Aliber, M. (2003). Chronic poverty in South Africa: Incidence, causes and policies. World Development, 31(3), pp. 473-90.

Atkinson, A. B. (1989). "Poverty" In: Eatwell, J., M. Millgate and P. Newman (eds.) Social Economics: The New Palgrave. Pp. 77 - 89. New York: Norton.

Armstrong, P., Lekezwa, B. and Siebrits, K. (2008). Poverty in South Africa: A profile based on recent household survey. Stellenbosch Economic Working Paper, No. $04 / 08$.

Barnett, V. (1991). Sample survey: principles and methods. London: Edward Arnold.

Binswanger, H. P and Khandker, S. R. (1995). The impact of formal finance on the rural economy of India. Journal of Development Studies, 32(2), pp. 234- 262.

Baulch, B. and Hoddinott, J. (2000). Economic mobility and poverty dynamics in developing countries. Journal of Development Studies, 88(6), pp.1- 24.

Case, A. and Deaton, A. (1998). Large cash transfers to the elderly in South Africa. Economic Journal, 108, pp. $1330-61$.

Carter, M. and May, J. (2001). One kind of freedom. World Development, 29, pp. 1987 2006.

Christianensen, L. J and Subbarao, K. (2005). Towards an understanding of vulnerability in rural Kenya. Journal of African Economies, 14(4), pp. 520 - 58.

CIA, (2008). The CIA world fact book. The Central Intelligence Agency. New York: Skyhorse Publishing. 
Deaton, A. (1997). The analysis of household surveys. Baltimore: Johns Hopkins University Press.

Deaton, A. and Muellbauer, J. (1980). Economics and consumer behaviour. New York: Cambridge University Press.

Dercon, S. (2001). Assessing vulnerability to poverty. Mimeographed. Oxford: Centre for the Study of African Economy, University of Oxford.

Ellis, F. (2000). Rural livelihoods and diversity in developing countries. Oxford: Oxford University Press.

Feilds, G.S., Chicello, P., Freije, S., Menendez, M. and Newhouse, D. (2002). For richer or for poorer? Evidence from Indonesia, South Africa, Spain and Venezuela. Mimeographed. Ithaca: Cornell University.

Feilds, G.S., Chicello, P., Freije, S., Menendez, M. and Newhouse, D. (2003). Household income dynamics. A four country story. Journal of Development Studies, 40(2), pp. $30-54$.

Hentschel, J. and Lanjouw, P. (1996). Constructing an indicator of consumption for the analysis of poverty: principles and illustrations with reference to Ecuador. Living Standards Measurement Study Working Paper No. 124. Washington DC: The Wold Bank.

Jalan, J. and Ravallion, M. (1999). Are the poor less insured? Evidence on vulnerability to income risk in rural China. Journal of Development Economics, 58(1), pp. 61 - 99.

Jalan, J. and Ravallion, M. (2000). Is transient poverty different? Evidence from rural China. Journal of Development Studies, 36(6), pp. $82-99$.

Klasen, S. (2000). Measuring poverty and deprivation in South Africa. Review of Income and Wealth, 46(1), pp. 33-58.

Klasen, S. and Woolard, I. (2001). Surviving unemployment without state support. Unemployment and household formation in South Africa. CESifo Working Paper Series 533. Munich: CESifo Group.

May, J., Carter M. and Posel, D. (1995). The composition and persistence of poverty in rural South Africa: an entitlement approach. (Policy Paper 15). Johannesburg: Land and Agriculture Policy Centre.

May, J. (ed) (1998). Poverty and inequality in South Africa: Report prepared for the Office of the Executive Deputy President and the Inter-Ministerial Committee for Poverty and Inequality. 13 May 1998. 
Ravallion, M. (1992). Poverty comparisons: a guide to concepts and methods. Living Standards Measurement Study Working Paper 88. Washington DC, World Bank.

Robert, B.J. (2001). Chronic and transitory poverty in post-apartheid South Africa: Evidence from KwaZulu-Natal. Journal of Poverty, 5(4), pp. 1 - 28.

Sen, B. (2003). Drivers of escape and descent: changing household fortune in rural Bangladesh. World Development, 31(3), pp. 513-34.

Statistics South Africa, (2005/06). Income and expenditure of households. Statistical Release, No. Po10o. Pretoria: Statistics South Africa.

Statistics South Africa, (2007a). General household survey (July, 2006). Statistical Release, No. Po318. Pretoria: Statistics South Africa.

Statistics South Africa, (2007b). A discussion note: Constructing comparable household survey data for the analysis of poverty in South Africa (1995-2000). Pretoria: Statistics South Africa.

Woolard, I. and Klasen, S. (2005). Determinants of income mobility and household poverty dynamics in South Africa. The Journal of Development Studies, 41(5), pp. 865-897.

World Bank, (2001). World development report 2000/2001: attacking poverty. The International Bank for Reconstruction and Development. New York: Oxford University Press.

World Bank. (2002). Pakistan poverty assessment - poverty in Pakistan: vulnerability, social gaps and rural dynamics. Washington, D. C.: World Bank.

World Bank, (2007). World development indicators 2007. Washington, D. C.: World Bank.

Zeller, M., Von Braun, J., Johm, K.B. and Puetz, D. (1994). Sources and terms of credit for the rural poor in the Gambia. African Review of Money, Finance and Banking, pp. $167-186$.

Zhang, Y. and Wan, G. (2006). An empirical analysis of household vulnerability in Rural China. Journal of the Asia Pacific Economy, 11(2), pp. 196 - 212. 